\title{
Evaluation of the oil Extract from Mentha spicata and its Chemical Constituents
}

\author{
Modupe Elizabeth Ojewumi ${ }^{1^{*}}$, Samuel Oluwafunsho Adedokun ${ }^{2}$, Ayodeji Ayodele Ayoola \\ ${ }^{3}$, Olugbenga Samson Taiwo ${ }^{4}$ \\ ${ }^{1 * 2,3}$ Chemical Engineering Department, ${ }^{4}$ Microbiology Department, Covenant University, \\ P.M.B 1023, Km 10, Idiiroko Road, Canaan land, Ota, Ogun State Nigeria. \\ ${ }^{1 *}$ Corresponding author e-mail: modupe.ojewumi@covenantuniversity.edu.ng \\ $1^{*}$ Orcid: 0000-0002-9254-2450
}

\begin{abstract}
Response surface methodology (RSM) has been employed to model and optimize the extraction of oil from Mentha spicata a local leaf used for several microbial and insect activities. The detailed effects of the solvents, weight of leaf $\left(\mathrm{X}_{1}\right)$ and time of extraction $\left(\mathrm{X}_{2}\right)$ have been studied. The interaction effects of these two (2) variables on the oil yield $\left(\mathrm{X}_{3}\right)$ have been investigated using Central Composite Design of experiments. The results were analyzed using MINITAB 17 software. Soxhlet extraction method was used with three (3) different solvents hexane, ethanol and petroleum ether. Petroleum ether gave the highest yield of oil using Response Surface Methodology. The oil extract of the leaf was analyzed using Gas Chromatography-Mass Spectrometry [GC-MS], about 15 components were discovered with Carvone as the most abundant [27.68\%.]. The antimicrobial activities of the oil extract against some fungi and bacteria viz., Pseudomonas aeruginosa, Bacillus Subtilis, Staphylococcus aureus, Aspergillus niger, Escherichia coli and Saccharomyces cerevisiae was evaluated. From the microbial analysis the zone of inhibitions indicated that the extract had strong activity against bacteria and fungi. Mentha spicata oil is rich in compounds with therapeutic activities and several substances of industrial interest. Carvone, Neophytadiene, methyl ester, palmitic acid and Linolenic were also discovered by the GC/MS analysis, presenting good microbial activity performance. The aim of this work was to establish the antimicrobial claim of the Mentha spicata oil extract.
\end{abstract}

Keywords: Mentha spicata, Soxhlet extraction, Response surface methodology, Yield, Design of experiments.

\section{INTRODUCTION}

Plant essential oils have been widely used for many years due to their antimicrobial properties in foods and pharmaceutical products (Laura et al., 2014). Mentha spicata has been used as a medicinal (microbial treatment) and aromatic plant since ancient times. Its English name is Spearmint which is $30-100 \mathrm{~cm}$ long and is characterized by its strong odor (Kordali et al., 2005; Thamarai et al., 2015; Alagesaboopathi, 2011). It is known for its distinctive smell which makes it very useful as a flavoring for foods. It is also used commonly as a domestic herbal 
remedy e.g treatment of skin infections caused by microorganisms such as ring worm and eczema. Its leaves are used for flavoring, tea infusions and spicing. In addition, mint oil is used to treat several diseases (Kil et al., 1995). Previous investigations have reported that various Mentha plant spp. extracts have displayed larvicidal effect on C. pipiens, C. quinquefasciatus, A.aegypti A. stephensi and Aedes tesselatus (Ansari and Razdan, 1995). Many extracts and essential oils isolated from these plants have been tested against different kinds of arthropods (Ojewumi et al., 2017a).

It has long been observed that plants' flowers, roots, leaves and seeds contain some active ingredients which are known as Essential oil. Some are odoriferous, some are volatile and Ethereal (being extractable with ether an organic solvent) (Ojewumi and Owolabi, 2012). N, $\mathrm{N}$-diethyl-3-methylbenzamide (DEET) is a synthetic chemical that is present in the most common mosquito-repellent formulations in the market. DEET is the most effective and best studied insect repellent currently in the market. DEET based synthetic mosquito repellent cause irreversible damage to ecosystem since they contain chemicals which are non-degradable in nature (Fradin, 1998; Klun et al., 2006). Synthetic insecticides are toxic and affect the environment by contaminating the soil, water and air (Ojewumi et al., 2018a). Local leaves oil extract especially Mentha spicata have been reported by various researchers as a good mosquito repellant and possess antimicrobial activity (Ojewumi et al., 2017a; 2012; Zaidi and Dahiya, 2015; Mirghani et al., 2012; Mgbemena et al., 2010; Bassole et al., 2011; Adeniyi and Ayepola, 2008).

Design of experiments (DOE) can be defined as the systematical method of determining the relationship between factors affecting a process and the output of that process. DOE is an advanced statistical tool to study efficiently the effect of a large number of variables with a minimum effort in data collection (Sail and Nyoman 2003; Ojewumi et al., 2017b). This investigates the effects of input variables (factors) on output variable (response) simultaneously. It is majorly used to find the cause-and-effect relationships, which is needed to manage process inputs in order to optimize the experimental outputs. In an experiment, one or more process factors or variables are deliberately changed in order to observe the effect the changes have on one or more response variables. The (statistical) design of experiments (DOE) is an efficient procedure for planning experiments so that the data obtained can be analyzed to yield valid and objective conclusions. An experimental design is the laying out of a detailed experimental plan in advance of doing the experiment. Simple experimental design and statistical tools for data analysis can provide much information about the system under investigation after only a few experiments. Such information can be key in decision-making for further experiments and can enable the development of robust and reliable protocols for chemical synthesis, analytical methods or biological assays (Ojewumi et al., 2017c; Ojewumi et al., 2018b).

\section{MATERIAL AND METHODS}

\section{Plant material}


Fresh Mentha leaves were obtained commercially from a mall in Lagos State, Nigeria. The leaves were washed with distilled water and air dried in a room for about two weeks. Figure 1 shows the picture of a freshly plucked leaf from Mentha plant. The plant was identified by an Agronomist, Dr. Adebayo a Lecturer in Ladoke Akintola University of Technology, Ogbomosho, Department of Chemical Engineering, Nigeria.

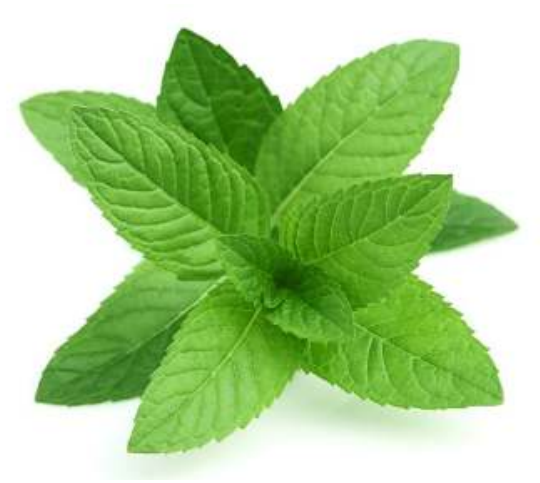

Fig. 1 Spear mint (Mentha spicata) (Source: leave search.net/gallery/521649.html)

\section{Extraction process}

The number of runs was determined by the design of experiment [DOE] using Central Composite Design factional factorial method with Minitab17 software. Soxhlet extraction method was used to carry out the extraction process using equal volume $(250 \mathrm{ml})$ of the three different solvents (hexane, petroleum ether and ethanol) (Ojewumi et al., 2017d).

\section{Microorganisms}

Clinical isolates of six microbes (four bacteria and two fungi) Pseudomonas aeruginosa, Bacillus Subtilis, Staphylococcus aureus, Aspergillus niger, Escherichia coli and Saccharomyces cerevisiae were obtained from the Applied Biology and Biotechnology Unit of the Department of Biological Sciences, Covenant University, Ota, Ogun State, Nigeria, using method of Ojewumi 2018c.

\section{Determination of Antimicrobial analysis}

The determination of antimicrobial activities in the oil extract of Mentha spicata leaf was carried out using Ojewumi et al., 2017e and 2018d, e, f, g method.

\section{Chromatographic analysis}

This was carried out using method (Suttida et al., 2012).

\section{Design of Experiment (DOE)}

MINITAB 17 (PA USA) was used for the design of experiments (DOE), plotting of response surfaces and optimization of \% oil yield composition in M. spicata leaf. Central Composite Design factional factorial design of experiments was used with the response surface method (RSM) for the establishment of optimum conditions with two operating factors. 


$\begin{array}{lclc}\text { Factors: } & 2 & \text { Replicates: } & 1 \\ \text { Base runs: } & 13 & \text { Total runs: } & 13 \\ \text { Base blocks: } & 1 & \text { Total blocks: } & 1\end{array}$

Two operating factors viz. $\mathrm{X}_{1}$ (weight) and $\mathrm{X}_{2}$ (time) were taken into consideration, to yield 13 runs.

\section{RESULTS AND DISCUSSION}

\section{Experimental Design for the Extraction Process}

Response surface regression analysis was done using MINITAB 17 software. Responses were generated as functions of two variables namely: $\mathrm{X}_{1}$ as weight [g] [dried M. spicata leaf] and $\mathrm{X}_{2}$ as time taken for the extraction to take place [hour.].

The response variable (\% Oil yield) was fitted by a second-order polynomial in order to correlate the design variables $\left(\mathrm{X}_{1}\right.$ and $\left.\mathrm{X}_{2}\right)$ which is presented by the model below:

$\mathrm{Y}=\alpha_{0}+\alpha_{1} \mathrm{X}_{1}+\alpha_{2} \mathrm{X}_{2}+\alpha_{1,1} \mathrm{X}_{1} \mathrm{X}_{1}+\alpha_{1,2} \mathrm{X}_{1} \mathrm{X}_{2}+\alpha_{2,2} \mathrm{X}_{2} \mathrm{X}_{2}$

The \% Oil yield responses is represented by $\mathrm{Y}$, which is associated with each factor level combinations. $\alpha_{0}, \alpha_{1}, \alpha_{2}, \alpha_{1,2} \ldots . \alpha_{2,2}$ are the regression coefficients: $X_{1}$ and $X_{2}$ are the factors. $\mathrm{X}_{1} \mathrm{X}_{1}, \mathrm{X}_{1} \mathrm{X}_{2}$ and $\mathrm{X}_{2} \mathrm{X}_{2}$ are the interactions of the variables.

Below are the best fitted models obtained from the regression analysis for the solvents used.

\section{Regression Equation (coded variables): for Hexane}

Equation 1 was decomposed and optimized with Minitab 7 software to obtain the optimum condition by which Oil extract of this leaf can be obtained. This is shown in equation 2 and applicable to the two remaining solvents.

$\%$ oil Yield $=-5.54+0.634 \mathrm{X}_{1}+3.499 \mathrm{X}_{2}-0.01989 \mathrm{X}_{1} * \mathrm{X}_{1}-0.1549 \mathrm{X}_{2} * \mathrm{X}_{2}-0.0111 \mathrm{X}_{1} * \mathrm{X}_{2}$

R-Sq. $\left[\mathrm{R}^{2}\right]=96.23 \%$

The optimized result obtained is:

$\begin{array}{lll}\% \text { oil Yield } & = & 17.5023 \\ \text { Weight }(\mathrm{g})= & 12.8931 \\ \text { Time }(\mathrm{hr}) \quad= & 10.8141 \\ \text { Fit Desirability }= & 0.95516\end{array}$

The result of the optimization for hexane solvent shows approximately that 13 grams with time of extraction 11 hours will be required to yield an optimum $\%$ oil yield of $18 \%$. 


\section{Regression Equation (coded variables): for Petroleum ether}

$\%$ oil Yield $=-5.61+0.651 \mathrm{X}_{1}+3.754 \mathrm{X}_{2}-0.02267 \mathrm{X}_{1} * \mathrm{X}_{1}-0.1750 \mathrm{X}_{2} * \mathrm{X}_{2}-0.0044 \mathrm{X}_{1} * \mathrm{X}_{2}$ 3

R-Sq. $\left[\mathrm{R}^{2}\right]=96.66 \%$

The optimized result obtained is:

$\begin{array}{lll}\% \text { Yield } & = & 18.5455 \\ \text { Weight }(\mathrm{g}) & = & 13.3216 \\ \text { Time }(\mathrm{hr}) & = & 10.5570\end{array}$

Fit Desirability $=0.96274$

The result of the optimization for petroleum ether solvent shows approximately that 13 grams with time of extraction 11 hours will be required to yield an optimum $\%$ oil yield of $19 \%$.

\section{Regression Equation (coded variables): for Ethanol}

$\%$ oil Yield $=-7.58+0.612 \mathrm{X}_{1}+2.631 \mathrm{X}_{2}-0.01333 \mathrm{X}_{1} * \mathrm{X}_{1}-0.1111 \mathrm{X}_{2} * \mathrm{X}_{2}-0.0378 \mathrm{X}_{1} * \mathrm{X}_{2} \ldots 4$

R-Sq. $\left[\mathrm{R}^{2}\right]=80.34 \%$

The optimized result obtained is:

$\begin{array}{ll}\% \text { Yield }= & 8.6704 \\ \text { Weight }(\mathrm{g})= & 8.1790 \\ \text { Time }(\mathrm{hr})= & 10.4713 \\ \text { Fit Desirability }= & 0.9468\end{array}$

$\mathrm{R}^{2}$ indicate the reliability of the model. The closer the $\mathrm{R}^{2}$ value to 1 , the stronger and better the model prediction of the responses.

The result of the optimization for ethanol solvent shows that approximately 9 grams with time of extraction 10 hours will be required to yield an optimum $\%$ oil yield of $9 \%$.

A 3-D (3 dimensional) response surface plots of Oil yield vs. (weight, Time) and an optimization plot for all the solvent used were plotted below (figure 2-3). These plots show the predicted effect of process variables $\left(\mathrm{X}_{1}, \mathrm{X}_{2}\right)$ on \% oil yield as the response. The 3-D plot represent graphically the regression coefficient in equation form in order to obtain the optimum conditions of the variables within the design region. . The Figures shows the parabolic increase of $\%$ oil yield with time. This means at higher time, more $\%$ oil yield is expected at minimal weight (for all three solvents used). However at maximum weight for hexane solvent (figure 2 ), it was observed that beyond 10 hours, the $\%$ oil yield started reducing. The same feature as 
shown for hexane occurred when petroleum ether solvent was used (Figure 3). Figure 4 showed that the $\%$ oil yield for ethanol can only be optimized below 9 hours at minimal weight (for ethanol solvent).

It was also observed from Figures 2-4 that, the yield obtained from using hexane and petroleum ether as solvents was higher compared to that obtained using ethanol. It was observed that there were no significant difference in the yield of the extract from hexane and that of petroleum ether. Ethanol on the other hand produced yield approximately half less than that of hexane and petroleum ether which is relatively low. This corresponds with previous studies from literature review that hexane and petroleum ether are very good solvents for extraction process but there is no significant difference in the yield of extract obtained from both (Ogbunugafor et al., 2011; Anwar and Rashid, 2007; Sengupta and Gupta, 1970).

For each of the solvents used, the weight of the samples and time were varied for optimization of the process. It was observed that the lowest yield of extract was recorded for 17.5 grams of the sample being extracted for 2 hours for all the solvents, while the highest yield of extract was recorded for 10 grams of the sample being extracted for 10 hours for all the solvents.

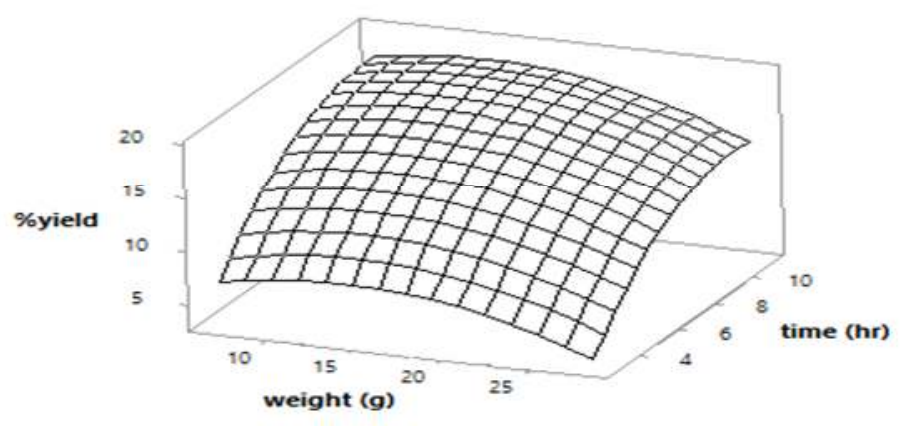

Fig. $2 \%$ yield against time and weight for hexane solvent. 


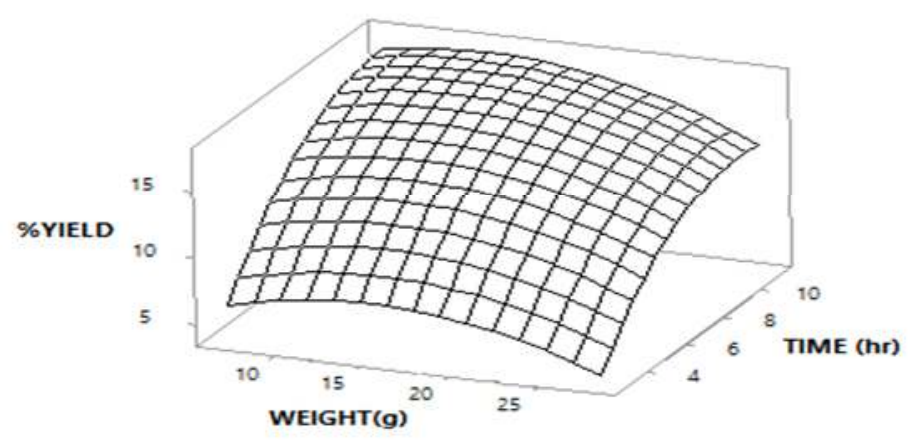

Fig. $3 \%$ yield against time and weight for petroleum ether solvent.

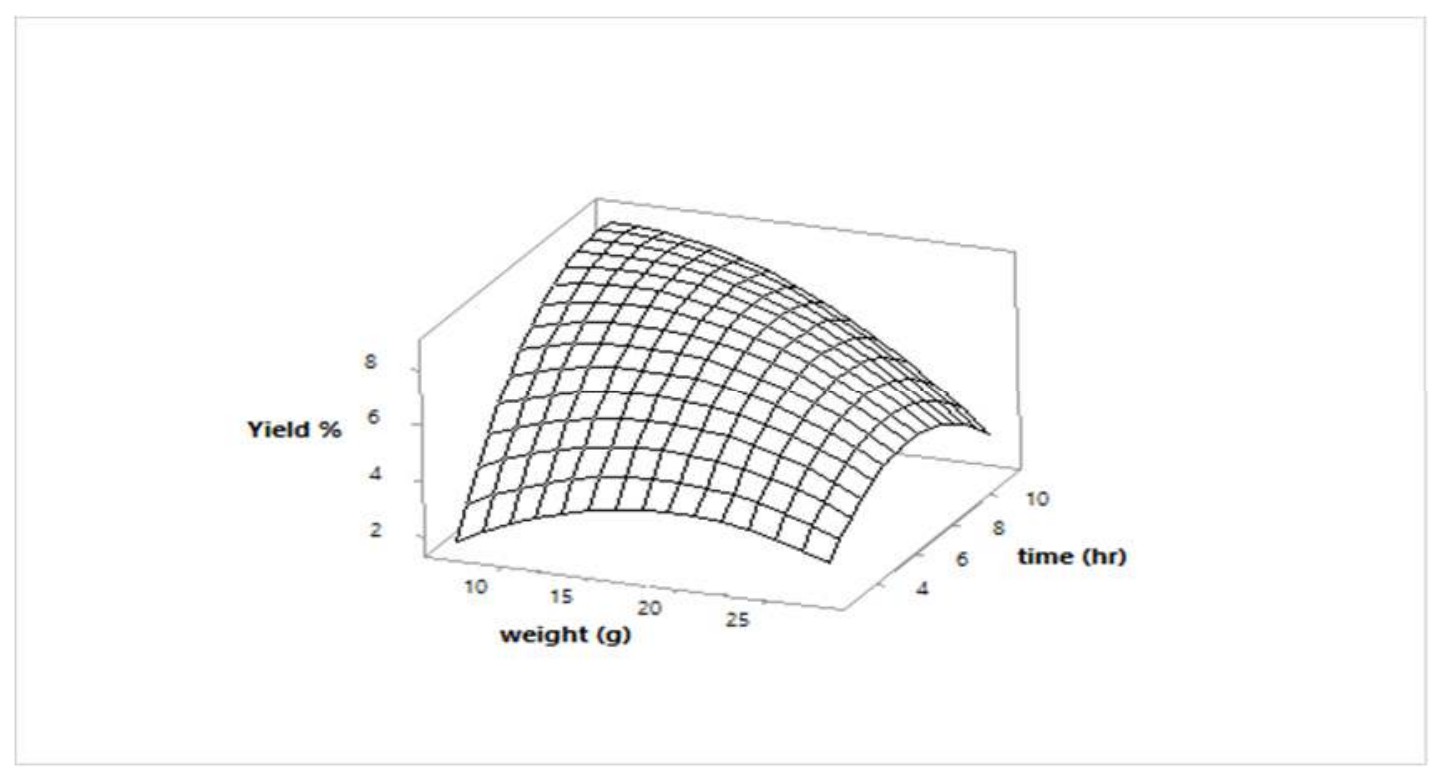

Fig. $4 \%$ yield against time and weight for ethanol solvent

Table 1 explains the experimental result obtained with DOE analysis while tables 2, 3 and 4 shows the application of the process simulation for the oil yield when Hexane, Petroleum ether and Ethanol were used as solvent respectively. Central Composite Design [CCD] of experiment was used for this analysis with the two chosen variables [weight and Time].

Tables 5, 6 and 7 shows the Optimization analysis for Hexane, Petroleum ether and Ethanol respectively. 
Table 1. Central Composite Design of experiments for the variables with $\%$ oil yield as the response

\begin{tabular}{llll}
\hline Run Order & Weight $\left[\mathrm{X}_{1}\right]$ & Time $\left[\mathrm{X}_{2}\right]$ & $\begin{array}{l}\% \\
{[\text { Oil }}\end{array}$ \\
\hline 1 & 25 & 4 & Yield \\
2 & 17.5 & 7 & 15 \\
3 & 17.5 & 7 & 15 \\
4 & 10 & 4 & 11 \\
5 & 17.5 & 7 & 15 \\
6 & 17.5 & 7 & 15 \\
7 & 10 & 10 & 18 \\
8 & 28.1 & 7 & 12 \\
9 & 17.5 & 11.2 & 17 \\
10 & 17.5 & 7 & 15 \\
11 & 25 & 10 & 14 \\
12 & 17.5 & 2.8 & 6.9 \\
13 & 6.9 & 7 & 13 \\
\hline
\end{tabular}

Table 2. Central Composite Design of experiments for the application of the Process simulation for \% Oil Yield in hexane

Factors

Weight

Time

\section{Notation}

$\mathrm{X}_{1}$

$\mathrm{X}_{2}$

\begin{tabular}{llllll}
\hline \multirow{2}{*}{ Run Order } & Weight $\left[\mathrm{X}_{1}\right]$ & Time $\left[\mathrm{X}_{2}\right]$ & $\begin{array}{l}\text { Experimental } \\
\text { values }\end{array}$ & $\begin{array}{l}\text { Predicted } \\
\text { values }\end{array}$ & \% Deviation \\
\hline 1 & 25 & 4 & 8 & 8.3 & 0.07 \\
2 & 17.5 & 7 & 15 & 15.0 & 0.14 \\
3 & 17.5 & 7 & 15 & 15.0 & 0.14 \\
4 & 10 & 4 & 11 & 9.9 & 0.10
\end{tabular}




\begin{tabular}{llllll}
\hline 5 & 17.5 & 7 & 15 & 15.0 & 0.14 \\
6 & 17.5 & 7 & 15 & 15.0 & 0.14 \\
7 & 10 & 10 & 18 & 17.2 & 0.17 \\
8 & 28.1 & 7 & 12 & 11.3 & 0.11 \\
9 & 17.5 & 11.2 & 17 & 17.0 & 0.16 \\
10 & 17.5 & 7 & 15 & 15.0 & 0.14 \\
11 & 25 & 10 & 14 & 14.6 & 0.13 \\
12 & 17.5 & 2.8 & 6.9 & 7.4 & 0.06 \\
13 & 6.9 & 7 & 13 & 14.3 & 0.12 \\
\hline Average value & & 174.9 & 174.9 & 1.739 \\
\hline
\end{tabular}

Table 3. Central Composite Design of experiments for the application of the Process simulation for \% Oil Yield of petroleum ether

\section{Factors}

Weight

Time

\section{Notation}

$\mathrm{X}_{1}$

$\mathrm{X}_{2}$

\begin{tabular}{llllll}
\hline \multirow{2}{*}{ Run Order } & Weight $\left[\mathrm{X}_{1}\right]$ & Time $\left[\mathrm{X}_{2}\right]$ & $\begin{array}{l}\text { Experimental } \\
\text { values }\end{array}$ & $\begin{array}{l}\text { Predicted } \\
\text { values }\end{array}$ & \% Deviation \\
\hline 1 & 25 & 4 & 8.4 & 8.2 & 0.07 \\
2 & 17.5 & 7 & 16 & 16.0 & 0.15 \\
3 & 17.5 & 7 & 16 & 16.0 & 0.15 \\
4 & 10 & 4 & 12 & 10.7 & 0.11 \\
5 & 17.5 & 7 & 16 & 16.0 & 0.15 \\
6 & 17.5 & 7 & 16 & 16.0 & 0.15 \\
7 & 10 & 10 & 19 & 18.2 & 0.18 \\
8 & 28.1 & 7 & 12 & 11.6 & 0.11 \\
9 & 17.5 & 11.2 & 18 & 18.1 & 0.17 \\
10 & 17.5 & 7 & 16 & 16.0 & 0.15
\end{tabular}




\begin{tabular}{llllll}
\hline 11 & 25 & 10 & 15 & 15.4 & 0.14 \\
12 & 17.5 & 2.8 & 6.8 & 7.6 & 0.06 \\
13 & 6.9 & 7 & 14 & 15.3 & 0.13 \\
\hline Average value & & 185.2 & 185.25 & 1.842 \\
\hline
\end{tabular}

Table 4. Central Composite Design of experiments for the application of the Process simulation for \% Oil Yield of Ethanol

\section{Factors}

Weight

Time

\section{Notation}

$\mathrm{X}_{1}$

$\mathrm{X}_{2}$

\begin{tabular}{llllll}
\hline Run Order & Weight $\left[\mathrm{X}_{1}\right]$ & Time $\left[\mathrm{X}_{2}\right]$ & $\begin{array}{l}\text { Experimental } \\
\text { values }\end{array}$ & $\begin{array}{l}\text { Predicted } \\
\text { values }\end{array}$ & \% Deviation \\
\hline 1 & 25 & 4 & 4 & 4.4 & 0.03 \\
2 & 17.5 & 7 & 7.4 & 7.4 & 0.06 \\
3 & 17.5 & 7 & 7.4 & 7.4 & 0.06 \\
4 & 10 & 4 & 6 & 4.4 & 0.05 \\
5 & 17.5 & 7 & 7.4 & 7.4 & 0.06 \\
6 & 17.5 & 7 & 7.4 & 7.4 & 0.06 \\
7 & 10 & 10 & 9 & 8.6 & 0.08 \\
8 & 28.1 & 7 & 6 & 4.7 & 0.05 \\
9 & 17.5 & 11.2 & 8 & 7.2 & 0.07 \\
10 & 17.5 & 7 & 7.4 & 7.4 & 0.06 \\
11 & 25 & 10 & 3.6 & 5.1 & 0.02 \\
12 & 17.5 & 2.8 & 2.8 & 3.6 & 0.02 \\
13 & 6.9 & 7 & 5.8 & 7.2 & 0.05 \\
\hline Average value & & & 82.2 & 82.18 & 0.812 \\
\hline
\end{tabular}


Table 5. Optimization table for hexane

\begin{tabular}{lllllllll}
\hline $\begin{array}{l}\text { Run } \\
\text { Order }\end{array}$ & Weight $\left(\mathrm{X}_{1}\right)$ & Time $\left(\mathrm{X}_{2}\right)$ & $\begin{array}{l}\% \\
\text { Yield }\end{array}$ & $\mathrm{X}_{1}$ & $\mathrm{X}_{2}$ & $\mathrm{X}_{1} \mathrm{X}_{1}$ & $\mathrm{X}_{1} \mathrm{X}_{2}$ & $\mathrm{X}_{2} \mathrm{X}_{2}$ \\
\hline 1 & 25 & 4 & 8 & 25 & 4 & 625 & 100 & 16 \\
2 & 17.5 & 7 & 15 & 17.5 & 7 & 306.3 & 122.5 & 49 \\
3 & 17.5 & 7 & 15 & 17.5 & 7 & 306.3 & 122.5 & 49 \\
4 & 10 & 4 & 11 & 10 & 4 & 100 & 40 & 16 \\
5 & 17.5 & 7 & 15 & 17.5 & 7 & 306.3 & 122.5 & 49 \\
6 & 17.5 & 7 & 15 & 17.5 & 7 & 306.3 & 122.5 & 49 \\
7 & 10 & 10 & 18 & 10 & 10 & 100 & 100 & 100 \\
8 & 28.1 & 7 & 12 & 28.1 & 7 & 790.0 & 196.7 & 49 \\
9 & 17.5 & 11.2 & 17 & 17.5 & 11.2 & 306.3 & 196.7 & 126.4 \\
10 & 17.5 & 7 & 15 & 17.5 & 7 & 306.3 & 122.5 & 49 \\
11 & 25 & 10 & 14 & 25 & 10 & 625 & 250 & 100 \\
12 & 17.5 & 2.8 & 6.9 & 17.5 & 2.8 & 306.3 & 48.3 & 7.6 \\
13 & 6.9 & 7 & 13 & 6.9 & 7 & 47.5 & 48.3 & 49 \\
\hline & & & & & & & & \\
\hline
\end{tabular}

Table 6. Optimization table for Petroleum ether

\begin{tabular}{lllllllll}
\hline $\begin{array}{l}\text { Run } \\
\text { Order }\end{array}$ & $\begin{array}{l}\text { Weight } \\
\left(\mathrm{X}_{1}\right)\end{array}$ & Time $\left(\mathrm{X}_{2}\right)$ & $\begin{array}{l}\% \\
\mathrm{Yield}\end{array}$ & $\mathrm{X}_{1}$ & $\mathrm{X}_{2}$ & $\mathrm{X}_{1} \mathrm{X}_{1}$ & $\mathrm{X}_{1} \mathrm{X}_{2}$ & $\mathrm{X}_{2} \mathrm{X}_{2}$ \\
\hline 1 & 25 & 4 & 8.4 & 25 & 4 & 625 & 100 & 16 \\
2 & 17.5 & 7 & 16 & 17.5 & 7 & 306.3 & 122.5 & 49 \\
3 & 17.5 & 7 & 16 & 17.5 & 7 & 306.3 & 122.5 & 49 \\
4 & 10 & 4 & 12 & 10 & 4 & 100 & 40 & 16 \\
5 & 17.5 & 7 & 16 & 17.5 & 7 & 306.3 & 122.5 & 49 \\
6 & 17.5 & 7 & 16 & 17.5 & 7 & 306.3 & 122.5 & 49
\end{tabular}




\begin{tabular}{lllllllll}
\hline 7 & 10 & 10 & 19 & 10 & 10 & 100 & 100 & 100 \\
8 & 28.1 & 7 & 12 & 28.1 & 7 & 789.9 & 196.7 & 49 \\
9 & 17.5 & 11.2 & 18 & 17.5 & 11.2 & 306.3 & 196.8 & 126.4 \\
10 & 17.5 & 7 & 16 & 17.5 & 7 & 306.3 & 122.5 & 49 \\
11 & 25 & 10 & 15 & 25 & 10 & 625 & 250 & 100 \\
12 & 17.5 & 2.76 & 6.8 & 17.5 & 2.8 & 306.3 & 48.3 & 7.603 \\
13 & 6.89 & 7 & 15 & 6.89 & 7 & 47.5 & 48.3 & 49 \\
\hline
\end{tabular}

Table 7. Optimization table for ethanol

\begin{tabular}{|c|c|c|c|c|c|c|c|c|}
\hline $\begin{array}{l}\text { Run } \\
\text { Order }\end{array}$ & $\begin{array}{l}\text { Weight } \\
\left(\mathrm{X}_{1}\right)\end{array}$ & Time $\left(\mathrm{X}_{2}\right)$ & $\begin{array}{c}\% \\
\text { Yield }\end{array}$ & $\mathrm{X}_{1}$ & $\mathrm{X}_{2}$ & $\mathrm{X}_{1} \mathrm{X}_{1}$ & $\mathrm{X}_{1} \mathrm{X}_{2}$ & $\mathrm{X}_{2} \mathrm{X}_{2}$ \\
\hline 1 & 25 & 4 & 4 & 25 & 4 & 625 & 100 & 16 \\
\hline 2 & 17.5 & 7 & 7.4 & 17.5 & 7 & 306.3 & 122.5 & 49 \\
\hline 3 & 17.5 & 7 & 7.4 & 17.5 & 7 & 306.3 & 122.5 & 49 \\
\hline 4 & 10 & 4 & 6 & 10 & 4 & 100 & 40 & 16 \\
\hline 5 & 17.5 & 7 & 7.4 & 17.5 & 7 & 306.3 & 122.5 & 49 \\
\hline 6 & 17.5 & 7 & 7.4 & 17.5 & 7 & 306.3 & 122.5 & 49 \\
\hline 7 & 10 & 10 & 9 & 10 & 10 & 100 & 100 & 100 \\
\hline 8 & 28.1 & 7 & 6 & 28.10 & 7 & 789.9 & 196.7 & 49 \\
\hline 9 & 17.5 & 11.24 & 8 & 17.5 & 11.24 & 306.3 & 196.7 & 126.4 \\
\hline 10 & 17.5 & 7 & 7.4 & 17.5 & 7 & 306.3 & 122.5 & 49 \\
\hline 11 & 25 & 10 & 3.6 & 25 & 10 & 625 & 250 & 100 \\
\hline 12 & 17.5 & 2.76 & 2.8 & 17.5 & 2.76 & 306.3 & 48.3 & 7.603 \\
\hline 13 & 6.89 & 7 & 5.8 & 6.89 & 7 & 47.5 & 48.3 & 49 \\
\hline
\end{tabular}




\section{GC/MS ANALYSIS}

Figures 5 and 6 shows GC-MS chromatogram of M. spicata oil extracted with Hexane and petroleum ether as solvent respectively while individual mass Spectrum of fragments of most abundant chemical constituents of the Hexane and petroleum ether extract were shown in figure 7 and 8 respectively, while tables 8 and 9 summarizes the constituent found in the oil extract of the leaf.

Figure 9 shows the structure of most abundant constituent found in the oil extract. Carvone is known to be a member of a family of chemicals called terpenoids. Its preferred IUPAC name is 2-Methyl-5-(prop-1-enn-2-yl) cyclohex-2-en-1-one. Carvone was found to be the most abundant component in the extract of M. spicata leaves with the area percentage of $27.68 \%$. Carvone has been suggested as a mosquito repellent in previous years and is currently under review to be used as a pesticide commercially. Its antimicrobial activities have also been reported by several researchers (Thamarai et al., 2015; Zaidi and Dahiya, 2015; Naseem et al., 2011). Figure 9 shows the structure of Carvone as identified by GC-MS.

Abundance

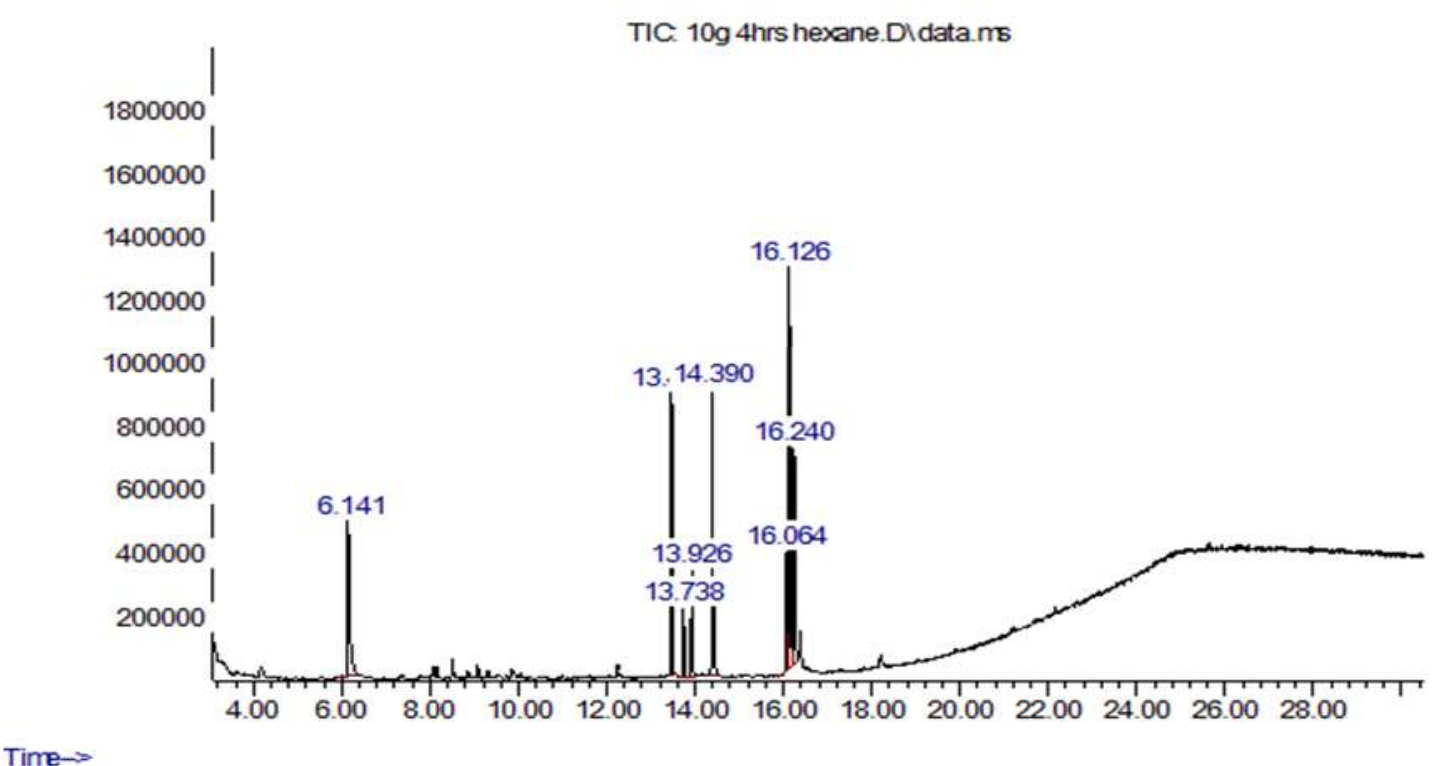

Fig. 5 GC-MS chromatogram of M. spicata oil extracted with Hexane solvent 


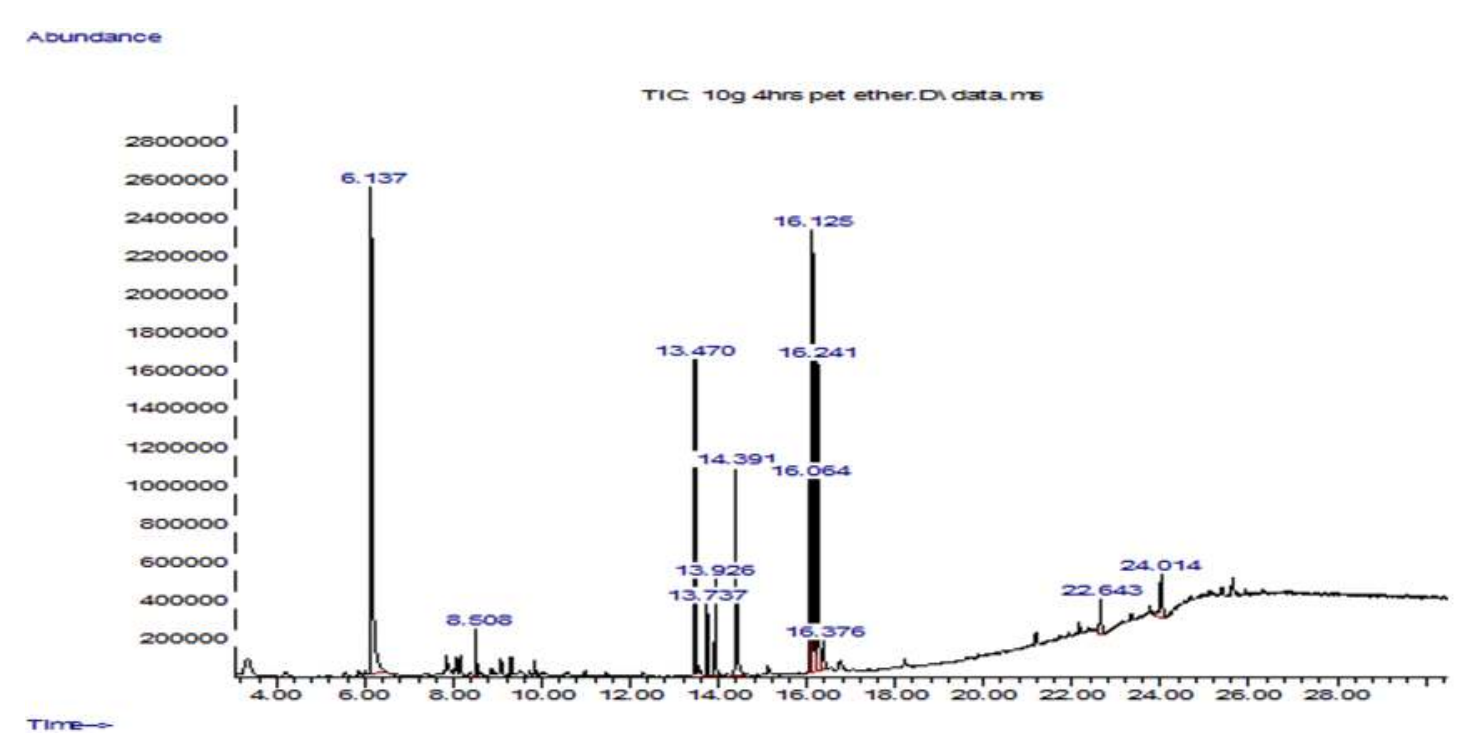

Fig. 6 GC-MS chromatogram of M. spicata oil extracted with Petroleum Ether solvent.

\section{GC/MS Analysis using Hexane as solvent}
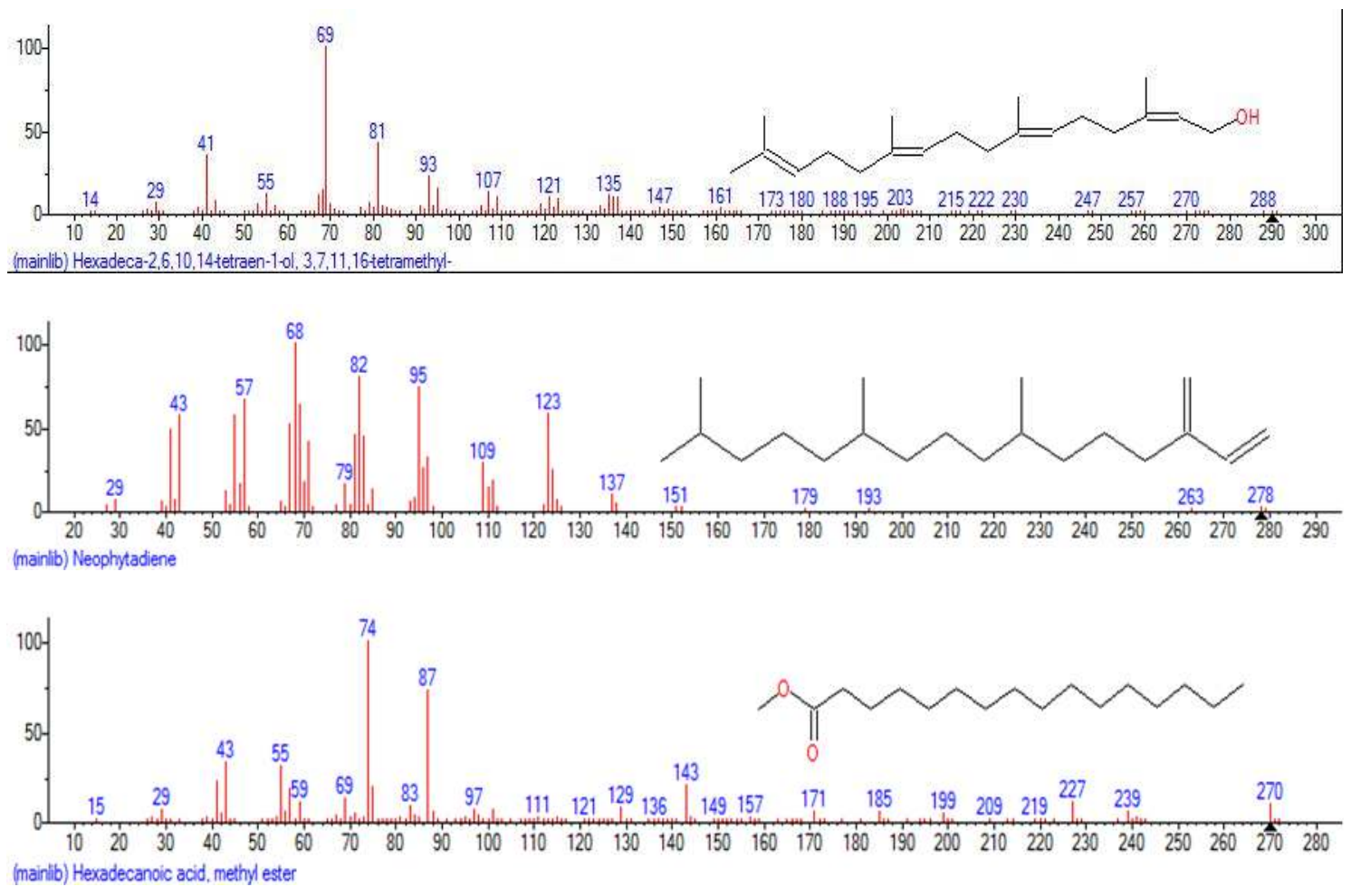

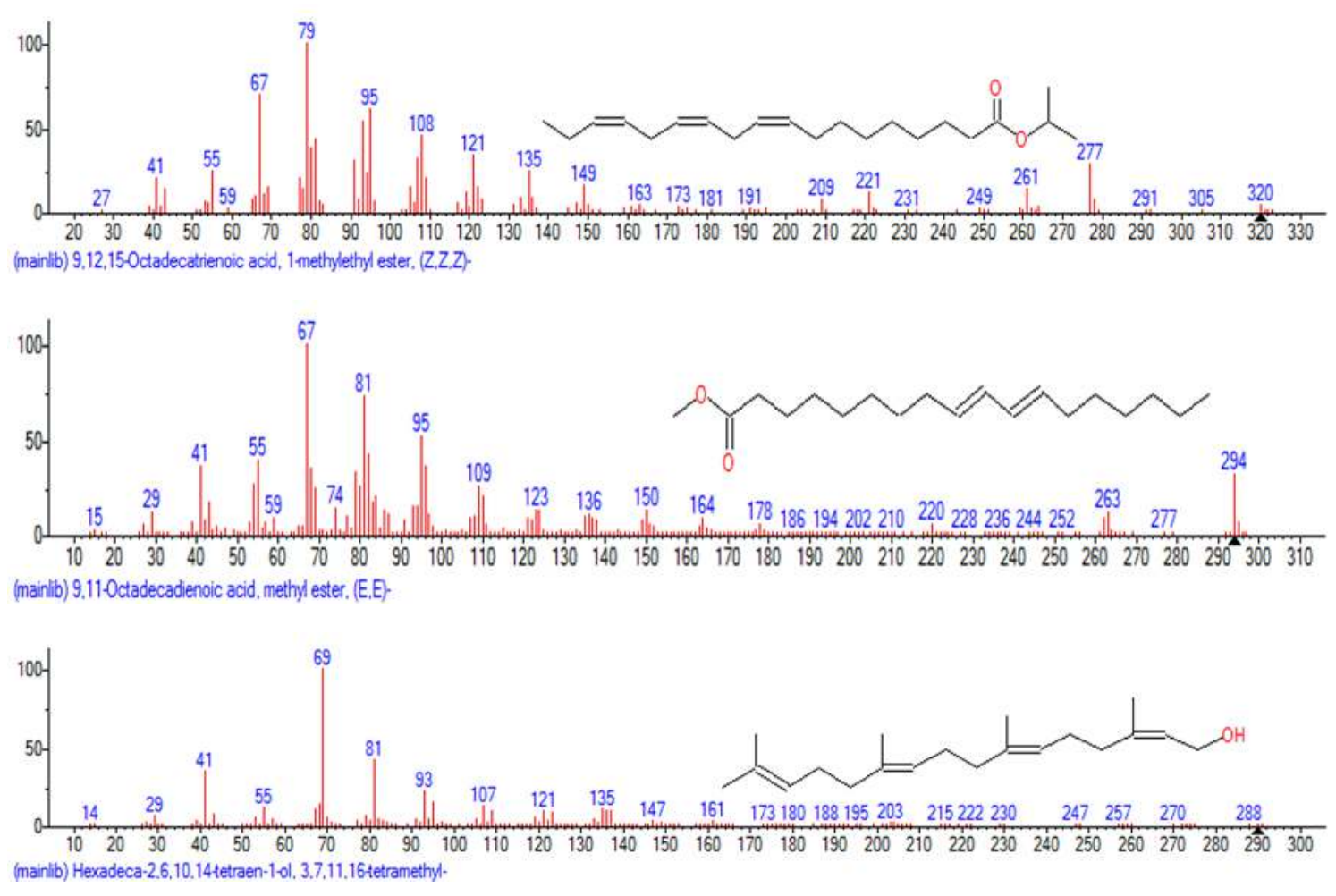

Fig. 7 Mass Spectrum of fragments of most abundant chemical constituents of the Hexane extract

\section{GC/MS Analysis using Petroleum Ether as solvent}
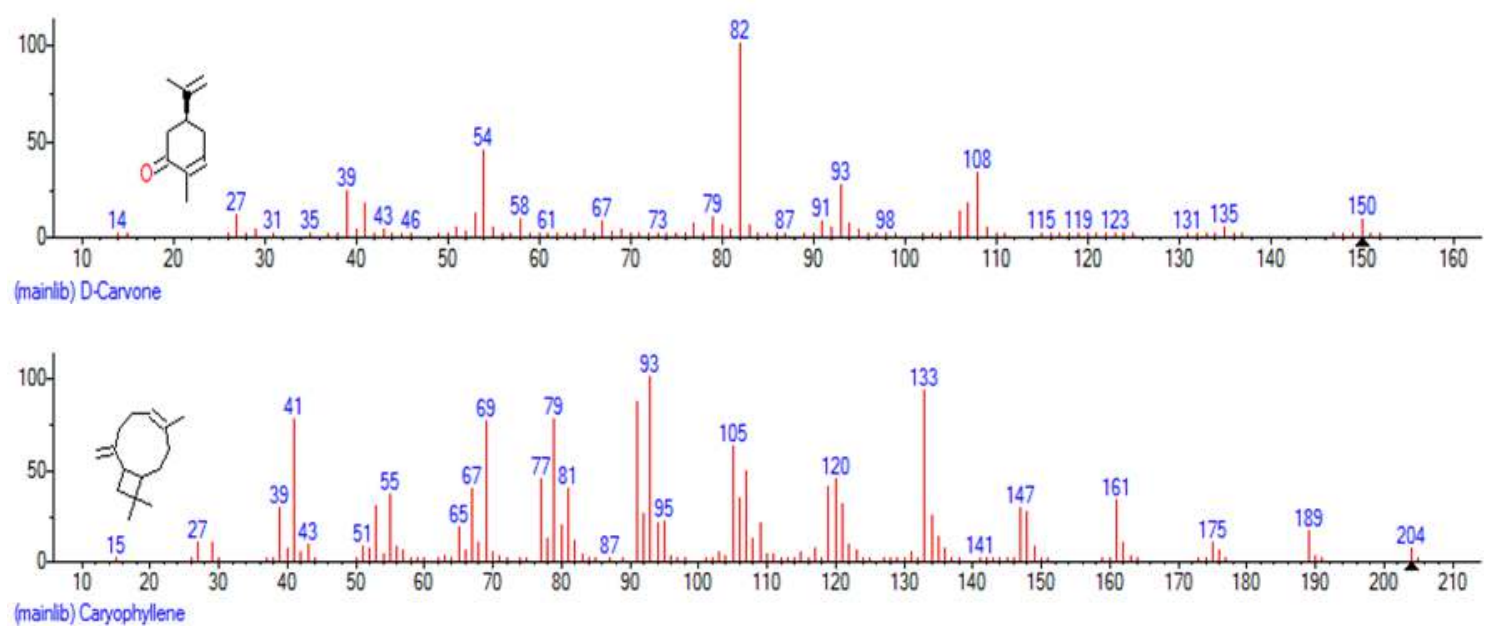

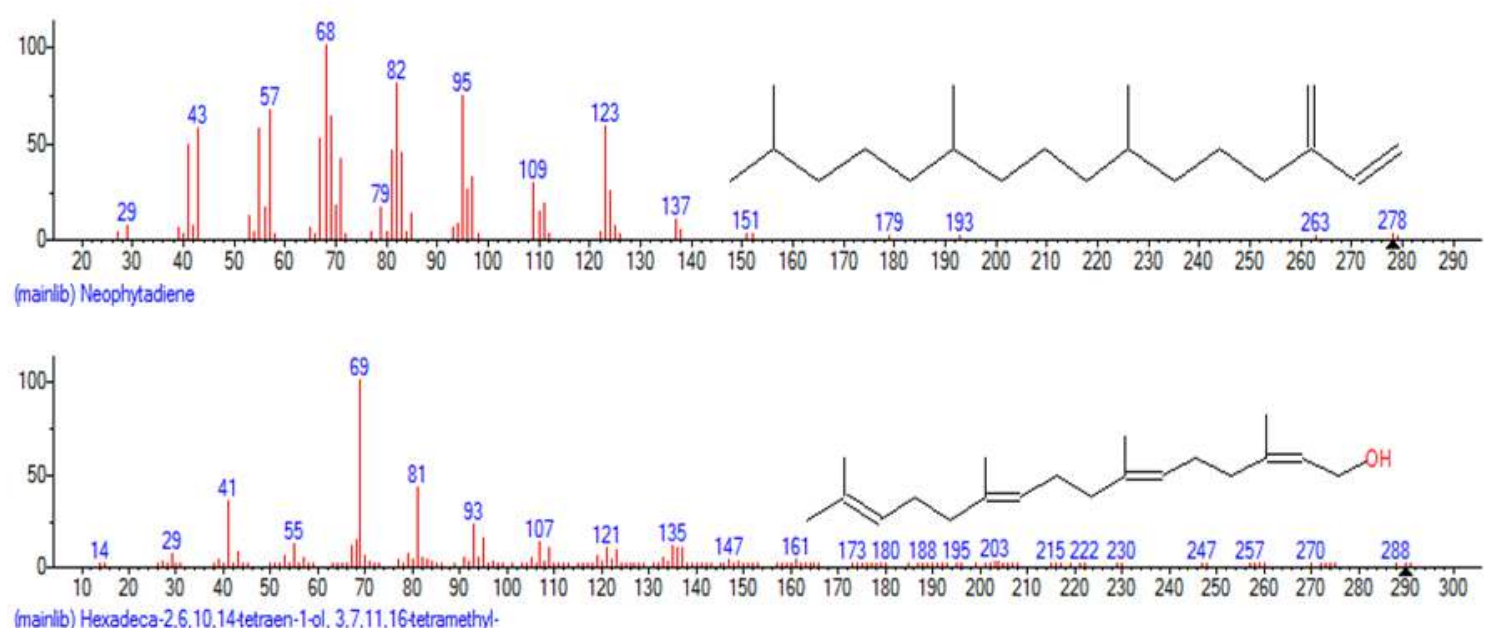
(mainib) Hexadeca-2,6,10,14tetraen-1-01, 3,7,11,16tetramethyl-
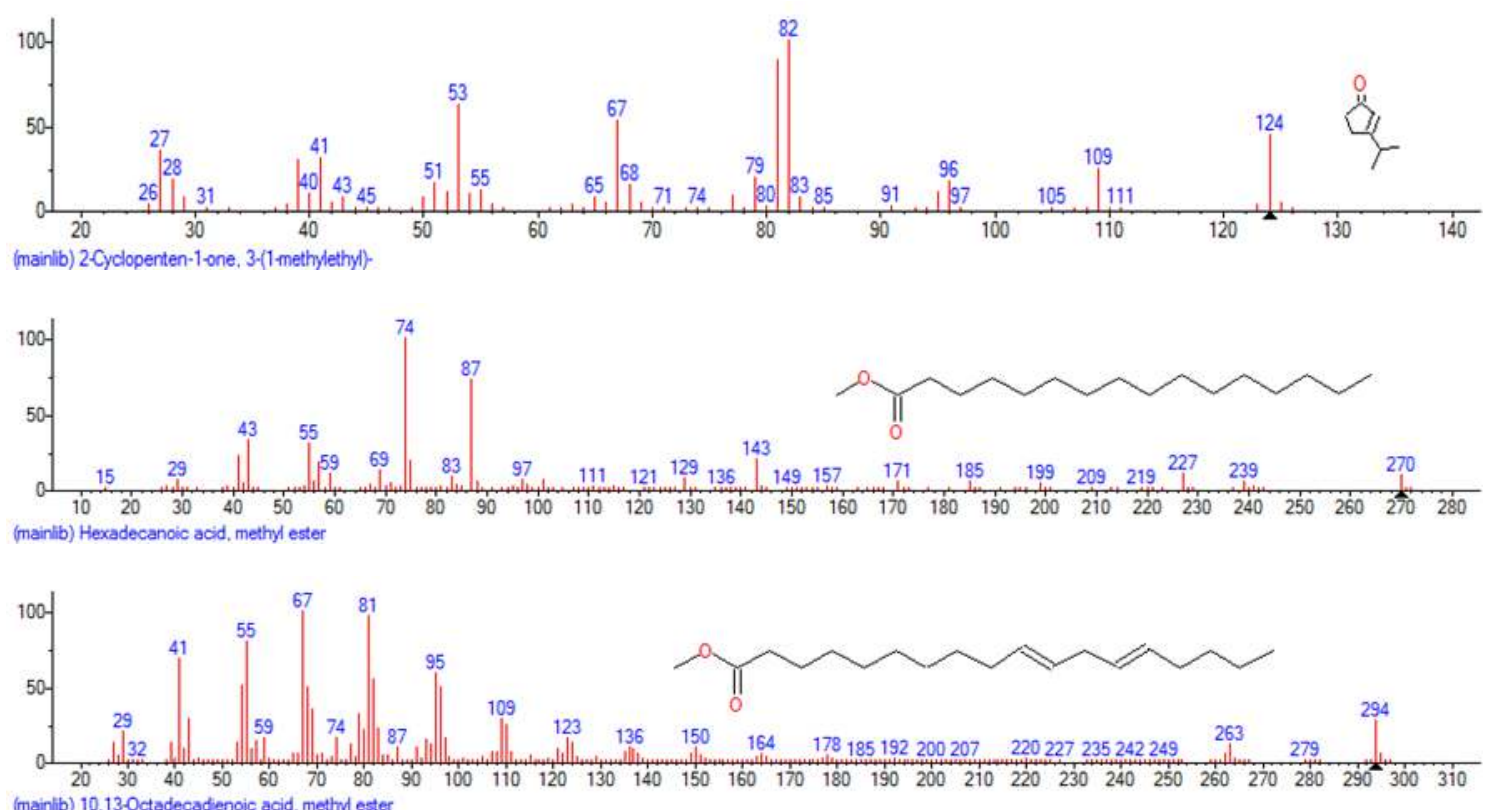
(mainib) 10.13-Octadecadienoic acid, methyl ester
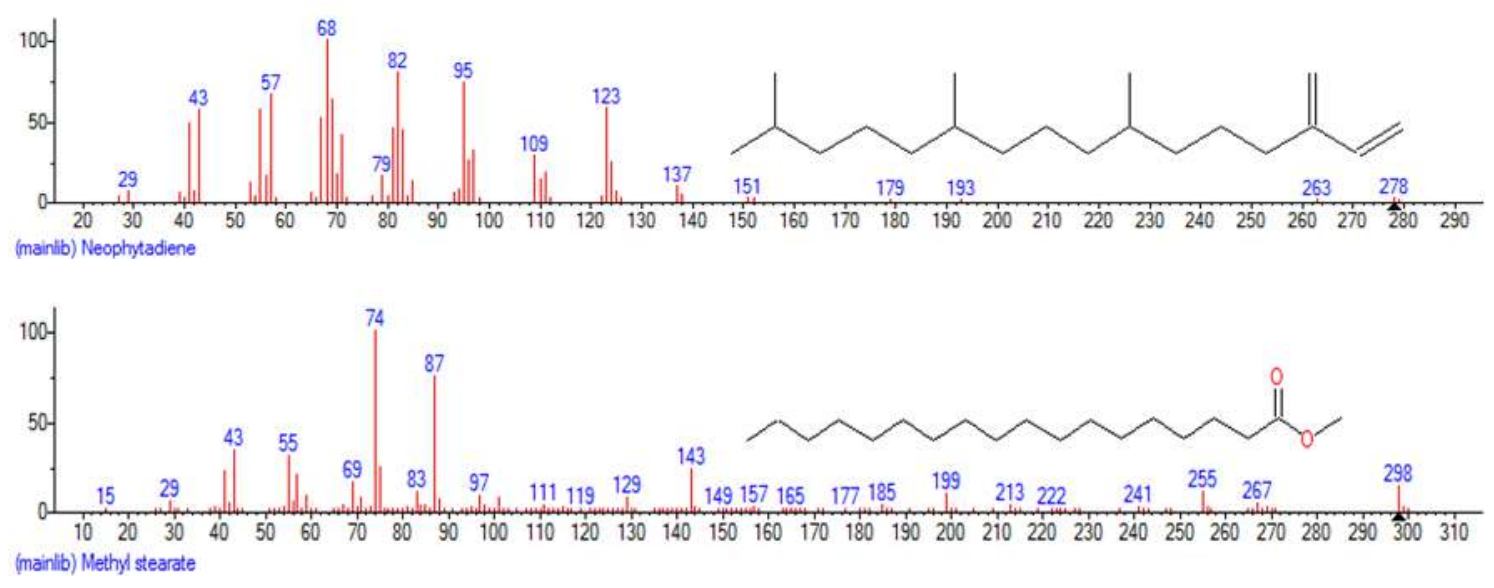

Fig. 8 Mass Spectrum of fragments of most abundant chemical constituent of the Petroleum ether extract 
Table 8. Chemical Constituents of the most abundant components in M. spicata oil using Hexane as solvent

\begin{tabular}{|c|c|c|c|}
\hline $\begin{array}{l}\text { Peak } \\
\text { Number }\end{array}$ & $\begin{array}{l}\text { Retention } \\
\text { time (min) }\end{array}$ & Component & Percentage in oil (\%) \\
\hline 1 & 6.142 & Carvone & 14.72 \\
\hline 2 & 13.472 & Neophytadiene, Dihexylcyclopropene & 13.75 \\
\hline 3 & 14.388 & Hexadecanoic acid & 17.49 \\
\hline 4 & 13.924 & 9-Octadecyne & 5.32 \\
\hline 5 & 16.064 & $\begin{array}{l}9,10,11,12,13,14-\text { Octadecadienoic } \\
\text { acid }\end{array}$ & 5.97 \\
\hline 6 & 16.127 & $9,12,15$-Octadecatrienoic acid & 25.43 \\
\hline 7 & 16.242 & $\begin{array}{l}\text { 3,7,11,15-Tetramethyl-2-hexadecen- } 1 \text { - } \\
\text { ol, 9-Octadecyne, Phytol }\end{array}$ & 13.94 \\
\hline
\end{tabular}

Table 9. Chemical Constituents of M. spicata most abundant components using Petroleum Ether as solvent

\begin{tabular}{|c|c|c|c|}
\hline $\begin{array}{l}\text { Peak } \\
\text { Number }\end{array}$ & $\begin{array}{l}\text { Retention } \\
\text { time (min) }\end{array}$ & Component & Percentage in oil (\%) \\
\hline 1 & 6.137 & Carvone & 27.68 \\
\hline 2 & 13.472 & Neophytadiene & 10.39 \\
\hline 3 & 14.394 & Hexadecanoic acid & 9.22 \\
\hline 4 & 16.064 & $\begin{array}{l}8,9,10,11,12,13,14-\text { Octadecadienoic } \\
\text { acid }\end{array}$ & 6.99 \\
\hline 5 & 16.127 & $9,12,15$-Octadecatrienoic acid & 18.05 \\
\hline 6 & 16.242 & $\begin{array}{l}\text { 3,7,11,15-Tetramethyl-2-hexadecen- 1-ol, } \\
\text { 9-Octadecyne }\end{array}$ & 13.19 \\
\hline
\end{tabular}




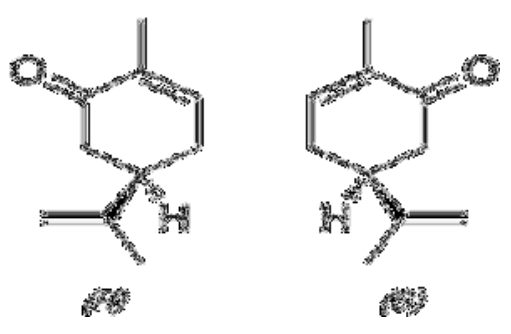

Fig. 9 Structure of Carvone

\section{Antimicrobial analysis}

Gentamicin $10 \mu \mathrm{m} \mathrm{ml}^{-1}$ was used as negative control, the antibacterial assay plates were incubated at $37^{\circ} \mathrm{C}$ for 24 hours, and the diameters of the zone of inhibition were measured in $\mathrm{mm}$. The lowest value which is regarded as low is $20 \mathrm{~mm}$ while values higher than $20 \mathrm{~mm}$ were regarded as sensitive, then further work on Minimum inhibition concentration (MIC) was recommended.

Table 10 explains the activity of the oil extract of $M$. spicata leaf on selected microorganisms using only the extract from Petroleum ether and Hexane.

This study showed that the leaf extract of M. spicata is an effective inhibitor of microbial growth as they showed varying degrees of activity on microorganisms (Table 10).

It was observed that $P$. aeruginosa and B. Subtilis resisted both extracts. The growth of the remaining two bacteria and two fungi were inhibited by the extract. The results also showed that the extract from petroleum ether had the highest activity against Staphylococcus aureus and $A$. niger followed by E. coli and lastly $S$. cerevisiae. The extract from hexane had the highest activity against $S$. aureus and $A$. niger followed by $E$. coli and lastly $S$. cerevisiae. It was observed that the activity of the two extracts were very similar as the measurements of the zones of inhibition are very close as seen in the table of results. This shows that there is no significant difference between the compositions of the extract from hexane and that of petroleum ether.

Table 10. Zone of Inhibition (mm)

\begin{tabular}{llllll}
\hline $\mathrm{S} / \mathrm{N}$ & organisms & $\mathrm{H}$ & $\mathrm{P} 1$ & $\mathrm{C}(\mathrm{H})$ & $\mathrm{C}(\mathrm{P})$ \\
\hline 1 & P. aeruginosa & 14.5 & 16.5 & - & - \\
2 & B. Subtilis & 10.5 & 11.5 & - & - \\
3 & E. coli & 25 & 26.5 & - & - \\
4 & S. aureus & 25.5 & 26.5 & - & - \\
5 & S.cerevisiae & 23 & 24.5 & - & - \\
6 & A. niger & 25.5 & 26.5 & - & - \\
\hline
\end{tabular}




\section{H- Hexane \\ $\mathrm{P}$ - Petroleum ether \\ $\mathrm{C}(\mathrm{H})$ - Hexane control \\ $\mathrm{C}(\mathrm{P})$ - Petroleum ether control}

\section{CONCLUSION}

The present study reveals that Hexane and Petroleum ether are better solvents for the extraction of oil from M. spicata leaf than ethanol, with petroleum ether presenting the most abundant component - Carvone. It can be concluded that oil yield was dependent on time and solvent used. RSM analysis revealed that with Petroleum Ether as solvent; 19\% oil yield will be obtained with $13 \mathrm{~g}$ of dried leaf for 11 hours which gave a very close results with Hexane. The active component of the extract was discovered to be Carvone. The extracts also showed the presence of various biologically active phytocomponents in GC-MS analysis. The presence of these phytocomponents also contributes to the observed medicinal property in addition to the antimicrobial activity of the plant.

\section{ACKNOWLEDGEMENTS}

The authors appreciate the sponsorship of Covenant University.

\section{CONFLICTS OF INTEREST}

The authors declare that they have no conflict of interest.

\section{REFERENCES}

Adeniyi BA., Ayepola OO. The phytochemical screening and antimicrobial activity of leaf extracts of Eucalyptus camaldulensis and Eucalypyus torelliana (myrtaceae). Res. J. Med. Plant. 2008;2(1):34-38.

Alagesaboopathi C. Antimicrobial Potential and Phytochemical Screening of Andrographis Affinis Nees: An Endemic Medicinal Plant from India. Int. J. Pharma. \& Pharm. Sci. 2011:3(2):157-159.

Ansari MA, Razdan RK. Relative efficacy of various oils in repelling mosquitoes. Ind. J. Malariology. 1995;(32):104-111.

Anwar F, Rashid U. Physico-chemical characteristics of Moringa oleifera seeds and seed oil from a wild provenance of Pakistan. Pak. J. Bot. 2007;(39): 1443-1453.

Bassole IHN, Lamien-Meda A, Bayala B, Obame L.C, llboudo AJ, Franz C, Novak J, Nebie RC, Dicko MH. Chemical composition and antimicrobial activity of Cymbopogon citratus and Cumbopogon giganteus essential oils alone and combination. Phytomed. J. $2011 ;(18): 1070-1074$. 
Fradin MS. Mosquitoes and mosquito repellents: a clinician's guide. Annals of Inter. Med. 1998;128(11):931-940.

Govindarajan M, Mathivanan T, Elumalai K, Krishnappa K, Anandan A. Ovicidal and repellent activities of botanical extracts against Culex quinquefasciatus Aedes aegypti and Anopheles stephensi (Diptera: Culicidae). Asian Pac. J. Trop. Biomed. 2011;(1):43-48.

Klun JA, Khrimian A, Rowton E, Kramer M, Debboun M. Biting deterrent activity of a deet analog, two DEPA analogs, and SS220 applied topically to human volunteers compared with DEET against three species of blood-feeding flies. J. Med. Ento. 2006;(43):12481251 .

Kil JP, Zdenka V, Fernando P, Reis B. Evaluation of drying parameters and desorption isotherms of garden mint leaves (Mentha crispa L.). J. Food Engr. 2002;51(3):193-199.

Kordali S, Kotan R, Mavi A, Cakir A, Ala A, Yildirim A. Determination of the chemical composition and antioxidant activity of the essential oil of Artemisia dracunculus and of the antifungal and antibacterial activities of Turkish Artemisia absinthium, A dracunculus, Artemisia santonicum and Artemisia spicigera essential oils. J. Agric. \& Food Chem. 2005;(53):9452-9458.

Laura Salvia-Trujillo M, Alejandra Rojas-Graü, Robert Soliva-Fortuny, Olga Martín-Belloso. Impact of microfluidization or ultrasound processing on the antimicrobial activity against Escherichia coli of lemongrass oil-loaded nanoemulsions. Food Control. 2014;292-297.

Mgbemena IC, Opara FN, Ukaoma A, Ofodu C, Ogbuagu DH. Prophylatic Potential of Lemon Grass and Neem as Antimalarial Agents. J. Ame. Sci. 2010;6(8):20-26.

Mirghani ME, Liyana S, Parveen J. Bioactivity analysis of lemongrass (Cymbopogan citratus) essential oil. Inter. Food Res. J. 2012;19(2):569-575.

Naseem U, Muhammad K, Farhat AK, Sahibzada UK, Muhammad UA, Saleem U, Umberin N, Said M, Javid H, Asif KM. Estimation of phytochemicals and antimicrobial activities of Mentha spicata from southern districts of KPK. J. Appl. Pharm. Sci. 2011;01(07):8184

Ogbunugafor HA, Eneh FU, Ozumba AN, Igwo-Ezikpe MN, Okpuzor J. Physico-chemical and antioxidant properties of Moringa oleifera seed oil. Pak. J. Nutr. 2011;(10):409414 .

Ojewumi ME, Owolabi RU. The effectiveness of the extract of 'Hyptis Sauveolens' leave (a specie of effinrin) in repelling mosquito. Transn. J. Sci. \& Tech. 2012;2(8):7987. 
Ojewumi ME, Banjo MG, Oresegun MO, Ogunbiyi TA, Ayoola AA, Awolu OO, Ojewumi EO. Analytical investigation of the extract of lemon grass leaves in repelling mosquito. Intern. J. Pharm. Sci. Res. 2017a; 8(5):2048-2055.

Ojewumi ME., Emetere ME., Babatunde DE., Okeniyi JO. In Situ Bioremediation of Crude Petroleum Oil Polluted Soil Using Mathematical Experimentation. Inter. J. Chem. Engr. Vol. 2017b, Article ID 5184760, 11 pages.

Ojewumi ME, Omoleye JA, Ajayi AA. Optimization of Fermentation Conditions for the Production of Protein Composition in Parkia biglobosa Seeds using Response Surface Methodology. Inter. J. App. Engr. Res. 2017c;12(22):12852-12859.

Ojewumi ME, Eluagwule B, Ayoola AA, Ogunbiyi AT, Adeoya J, Eterigho ME, Joseph OO. Termiticidal effects of African locust bean seed oil extract. Inter. J. Cur. Res. 2017d;9:(07):53929-53934.

Ojewumi ME, Adedokun SO, Omodara JO, Oyeniyi EO, Taiwo OS, Ojewumi EO. Phytochemical and Antimicrobial Activities of the Leaf Oil Extract of Mentha Spicata and its Efficacy in Repelling Mosquito. Inter. J. Pharm. Res. \& Alli. Sci. 2017e;6(4):1727.

Ojewumi ME, Adeyemi AO, Ojewumi EO. Oil Extract From Local Leaves - An Alternative to Synthetic Mosquito Repellants. Pharmacophore, 2018a; 9(2):1-6.

Ojewumi ME, Omoleye JA, Ajayi AA, Alagbe EE. Evaluation of fermentation rate for the production of a protein based African seed condiment, Preprints (www.preprints.org) 22 June (2018b). doi:10.20944/preprints201806.0359.v1.

Ojewumi ME, Kayode GO, Emetere ME, Okeniyi JO. Data on the rheological behavior of cassava starch paste using different models, Data in Brief, 2018c. 19(2018), 2163-2177. https://doi.org/10.1016/j.dib.2018.06.112.

Ojewumi ME, Ejemen VE, Taiwo OS, Adekeye BT, Awolu OO, Ojewumi EO. A Bioremediation Study of Raw and Treated Crude Petroleum Oil Polluted Soil with Aspergillus niger and Pseudomonas aeruginosa, J. Ecol. Eng., 2018d;19(2): 226-235. https://doi.org/10.12911/22998993/83564.

Ojewumi ME, Okeniyi JO, Ikotun JO, Okeniyi ET, Ejemen VA, Poopola API. Bioremediation: Data on Pseudomonas aeruginosa Effects on Bioremediation of Crude Oil Polluted Soil, Data in Brief, 2018e. 19(2018), 101-113. https://doi.org/10.1016/j.dib.2018.04.102.

Ojewumi ME, Job AI, Taiwo OS, Obanla OM, Ayoola AA, Ojewumi EO, Oyeniyi EA. BioConversion of Sweet Potato Peel Waste to Bio-Ethanol Using Saccharomyces Cerevisiae, International Journal of Pharmaceutical and Phytopharmacological Research (eIJPPR) 2018f, 8(3): 46-54. 
Ojewumi ME, Obielu BI, Emetere ME, Awolu OO, Ojewumi EO. Alkaline Pre-Treatment and Enzymatic Hydrolysis of Waste Papers to Fermentable Sugar, Journal of Ecological Engineering, 2018 g, 19(1): 211-217. https://doi.org/10.12911/22998993/79404.

Salil Kumar Roy, Nyoman Sutapa. Case Studies of Use of Design of Experiments in Material Research Jurnal Teknik Industrial, 2003;5(1):32 - 40.

Sengupta A, Gupta MP. Studies on Seed Fat Composition of Moringaceae Family. Fette Seifen Anstrich. 1970;72(1): 6-10.

Suttida W, Richard LD, Nuansri R. Characterization of Soybean Kapi during Fermentation with Bacillus spp. Food Biotech. 2012; 26:199-217.

DOI: $10.1080 / 08905436.2012 .698768$

Thamarai S, Poovizhi KJ, Senthi KV. Study on the Phytochemical Analysis and Antioxidants, Antimicrobial Activity of Medicinal Plants against Fish Pathogen. J. Med. Sci. \& Clin. Res. 2015;3(10):7778-7799.

Zaidi S, Dahiya P. In vitro antimicrobial activity, phytochemical analysis and total phenolic content of essential oil from Mentha spicata and Mentha piperita. Inter. Food Res. J. 2015;22(6):2440-2445. 